\title{
Choline and betaine intakes are associated with reduced risk of nasopharyngeal carcinoma in adults: a case-control study
}

\author{
F-f Zeng ${ }^{1,7}, C-h X^{1,2,7}$, Y-t Liü ${ }^{1,3,7}$, Y-y Fan ${ }^{4}$, X-I Lin ${ }^{5}$, Y-k Lu ${ }^{6}$, C-x Zhang ${ }^{1}$ and Y-m Chen ${ }^{*, 1}$
}

${ }^{1}$ Guangdong Provincial Key Laboratory of Food, Nutrition and Health, Department of Medical Statistics \& Epidemiology, School of Public Health, Sun Yat-sen University, Guangzhou 510080, China; ${ }^{2}$ Tactic Training Section of Criminal Investigation, Guangdong Provincial Security Department, Guangzhou 510050, China; ${ }^{3}$ Information Section, Central Hospital of Panyu District, Guangzhou 511400, China; ${ }^{4}$ Department of Nasopharyngeal Carcinoma, Sun Yat-sen University Cancer Center, Guangzhou 510060, China; ${ }^{5}$ Department of Gynecologic Oncology, Sun Yat-sen University Cancer Center, Guangzhou 510060, China and ${ }^{6}$ Sun Yat-sen University Ophthalmic Center, Guangzhou 510060, China

Background: Intakes of choline and betaine have been inversely related to the risk of various neoplasms, but scant data exist on nasopharyngeal carcinoma (NPC). We examined the association between consumption of choline and betaine and risk of NPC.

Methods: We conducted a case-control study with 600 incident NPC patients and 600 controls 1:1 matched by age, sex and household type in Guangdong, China. Dietary intake was assessed by a food frequency questionnaire through face-to-face interview.

Results: Intakes of total choline, betaine and choline + betaine were inversely related to NPC after adjustment for various lifestyle and dietary factors (all $P$-trend $<0.001)$. Adjusted odds ratios $(95 \% \mathrm{Cl})$ for quartile 4 (vs quartile 1 ) were $0.42(0.29,0.61)$ for total choline, $0.50(0.35,0.72)$ for betaine and $0.44(0.30,0.64)$ for betaine + total choline. Regarding various sources of choline, lower NPC risk was associated with greater intakes of choline from phosphatidylcholine, free choline, glycerophosphocholine and phosphocholine, but not sphingomyelin.

Conclusion: These findings are consistent with a beneficial effect of choline and betaine intakes on carcinogenesis.

Although nasopharyngeal carcinoma (NPC) is a rare neoplasm in most regions of the world (an incidence of $<1$ per $10^{5}$ personyears), particularly high incidences have been observed in southern China, especially in the province of Guangdong (20-50 per $10^{5}$ person-years) (Jia et al, 2006; Bray et al, 2008). According to statistical data reported by the International Agency for Research on Cancer, 33101 new cases of NPC were diagnosed in China in 2008 , accounting for $\sim 40 \%$ of new cases worldwide (Ferlay et al, 2008). Most of these cases occurred in persons $40-59$ years of age and thus have the potential for enormous social devastation (Lee et al, 2003). Therefore, preventive strategies would have substantial benefit in this region. Development of NPC depends on the interaction between genetic susceptibility and environmental factors (for example, Epstein-Barr virus infection, exposure to carcinogens, dietary factors) (Lee et al, 2003). With the exception of salted fish (Lee et al, 2003), the role of dietary components is poorly understood.

Choline is an essential nutrient widely distributed in animals and plants (Laird and Jaenisch, 1994). Although choline is endogenously synthesised, a choline-deficient diet leads to deficiency in humans (Zeisel et al, 1991). Choline is oxidised to betaine, which is linked to folate and serves as a methyl donor in one-carbon metabolism to affect the DNA methylation level in vivo (Laird and Jaenisch, 1994). DNA methylation is postulated to have an important role in carcinogenesis (Laird and Jaenisch, 1994). Deficiencies in dietary choline and betaine could increase the

*Correspondence: Professor Y-m Chen; E-mail: chenyum@mail.sysu.edu.cn

${ }^{7}$ These authors contributed equally to this work.

Received 17 July 2013; revised 2 October 2013; accepted 8 October 2013; published online 29 October 2013

(c) 2014 Cancer Research UK. All rights reserved 0007-0920/14 
probability of hypomethylation independent of folate levels (Shin et al, 2010) and predispose an individual to the development of neoplasia.

Recent epidemiological studies have revealed an inverse association between choline and/or betaine intake and several types of cancers such as breast cancer (Xu et al, 2009; Zhang et al, 2013), lung cancer (Ying et al, 2013) and oesophageal cancer (Ibiebele et al, 2011). From the results of these studies, it is reasonable to speculate that choline and/or betaine intake affects the risk of NPC. However, to our knowledge, there has been no epidemiological study pertaining to the association between dietary choline and/or betaine intake and the risk of NPC. Therefore, the primary goal of our study was to investigate whether intake of dietary choline and/or betaine has protective effects on the risk of NPC in a Chinese population. We also examined the modification of the effect by some potential risk factors, such as folate intake and alcohol consumption, because these factors might interact with choline to alter methylation levels (Cho et al, 2007b).

\section{PARTICIPANTS AND METHODS}

Study participants. Between July 2009 and March 2011, we conducted a $1: 1$ matched case-control study in Guangzhou, Guangdong Province, China. The design of the study was described previously (Liu et al, 2012).

In brief, the subjects of the study were patients with histologically confirmed NPC who were hospitalised at Sun Yat-sen University Cancer Center. Patients were included if they were 30-75 years of age, had been diagnosed with NPC within the prior 3 months and had resided in Guangdong Province for more than 10 years. Patients were excluded if they had a family history of NPC within three generations, their dietary habits had changed significantly within the previous 5 years, they were presently suffering a chronic disease (for example, diabetes, stroke, cataract or poor vision) that might influence their dietary habits or affect their routine activities, or they could not speak Mandarin/ Cantonese. In addition, patients who reported implausible values for total energy intake ( $<700$ or $>4200 \mathrm{kcal}$ per day for males; $<500$ or $>3500 \mathrm{kcal}$ per day for females), had insufficient data, or refused to participate, were excluded. Of the 653 eligible patients, 600 (91.9\%) were retained for these analyses. Among the NPCs, $570(95.0 \%)$ were classified as undifferentiated (type III), and 558 (93.0\%) were VCA-IgA seropositive.

One age- ( \pm 3 years), sex- and household type- (urban $v s$ rural for the previous 10 years) matched hospital-based control subject was recruited per NPC patient. Control subjects were selected from the Sun Yat-sen University Ophthalmic Center. The same inclusion and exclusion criteria that were applied to the NPC patients were applied to the control subjects, with the exception of a history of NPC. Of the 600 control subjects, 249 (41.3\%) suffered ocular fundus disease, 111 (18.5\%) suffered glaucoma, 107 (17.8\%) suffered ocular trauma and $133(22.2 \%)$ suffered another ocular disease.

The study was approved by the ethics committee of the School of Public Health of Sun Yat-sen University, and written informed consent was obtained from all participants.

Dietary assessment. Dietary intake information was obtained from all participants by means of a semi-quantitative 78-item food frequency questionnaire (FFQ) (Zhang and Ho, 2009). The reference period for the dietary survey was the year prior diagnosis in NPC patients or to interview in control subjects. For each food item on the FFQ, participants chose from five qualitative responses ranging from never to daily and reported the intake amount. Photographs of food portion sizes were provided to help FFQtakers estimate the amount of food consumed. Individual food items were then converted to a daily intake value (g per day). Individual nutrient or energy intake was calculated by multiplying the daily intake of each food item by the nutrient content in $100 \mathrm{~g}$, then divided by 100 (obtained from the China food composition table, 2004) (Yang et al, 2004).

Our database for dietary betaine and choline intake has been described in detail elsewhere (Zhang et al, 2013). Briefly, the betaine and choline contents of foods were determined on the basis of the composition analysis conducted by Zeisel et al (2003a,b). Intakes of betaine and choline subclasses, including choline from glycerophosphocholine, free choline, phosphocholine, phosphatidylcholine and sphingomyelin, were calculated as the sum of the daily intake of each food multiplied by the betaine and choline content in $100 \mathrm{~g}$, then divided by 100 . Total choline intake was calculated as the sum of intakes of the five subclasses.

The reproducibility and validity of the FFQ were assessed previously with six 3-day energy-adjusted diet records at intervals of 2 months over a 12-month period and two FFQs administered 1 year apart and completed by 61 local female subjects (Zhang and Ho, 2009; Zhang et al, 2013). The Pearson's correlation coefficients for betaine and total and individual choline intakes ranged from 0.23 to 0.48 in comparing the second FFQ and 18-day dietary records and from 0.44 to 0.67 in comparing the two FFQs (23).

Other covariates. Intakes of energy and nutrients were determined from the FFQ described above. Information on demographics, socioeconomic factors, occupational and domestic exposure to toxic substances, lifestyle, history of chronic disease(s), use of medications and physical activity over the previous 12 months was obtained by means of a standardised questionnaire. According to labour intensity, occupation were grouped into light occupation (administrative staff, health care staff, teachers, clerks, financial and legal staff, engineering technicians), moderate occupation (businessmen and service personnel, culture and arts personnel, housewives and self-employed persons), or heavy activity occupation (uniformed security personnel, workers, farmers and fishermen). For the exposures to toxic materials or detrimental environment, we interviewed participants if they had never or ever occupational exposure of either one of the following factors over 1 year: heat, organic solvents, pesticides, heavy metals, smoke from burning incense, anti-mosquito coils, new furniture or decoration and radiation. Participants' height $(\mathrm{m})$ and weight $(\mathrm{kg})$ were measured on digital scales, and body mass index (BMI) $\left(\mathrm{kg} \mathrm{m}^{-2}\right)$ was calculated. Questionnaires were administered and measurements were taken by trained interviewers in the same manner for all participants, and each interviewer completed an equal number of NPC patient and control subject interviews.

Statistical analysis. Data were analysed using SPSS version 17.0 for WINDOWS (SPSS Inc, Chicago, IL, USA). All $P$-values are two-sided, and statistical significance was considered to be $P<0.05$.

As no statistically significant interactions were found, all analyses were performed for men and women combined. We used a residual nutrient method (diseases risk $=\beta 1$ nutrient residual + $\beta 2$ total energy) established by Willett et al (1988) to adjust for energy intake for betaine and total choline and its subclasses. We grouped energy-adjusted intakes of betaine and choline and its subclasses into quartiles (Q1-Q4) based on control subjects by sex, and the sex-specific cutoffs were then applied to the NPC patients. The lowest quartile (Q1) served as the reference group. Conditional logistic regression was used to assess the association between energy-adjusted dietary betaine and total and individual choline intakes and the risk of NPC, and the associations were expressed as odds ratios (ORs) with 95\% confidence intervals (CIs). In our multivariable model, we adjusted for age (year), BMI $\left(\mathrm{kg} \mathrm{m}^{-2}\right)$, occupation (light, moderate or heavy activity), marital status (married, unmarried/divorced/widowed), education level (primary 
school or below, secondary school, high school, college or above), household income ( $\leqslant 500,501-1500,1501-3000$ or $>3000$ yuan/ month/person), current smoking (yes or no), current drinking (yes or no), exposure to toxic substances (yes or no), multivitamin supplement use during the past year (yes or no), history of chronic rhinitis (yes or no), physical activity (MET-h per day), dietary folate intake ( $\mu$ g per day) and log-transformed daily energy intake (kcal per day). These variables were screened by the forward stepwise method and only significant variables were included in the final multivariable model, and criteria for entry and non-entry of covariates were $P<0.05$ and $P>0.10$, respectively. Linear trends across increasing quartiles were tested by assigning quartiles as continuous variables in the regression. We repeated our main analysis using unconditional logistic regression and found the results to be essentially the same (Appendix).

To determine whether the total choline intake-NPC relation was modified by potential risk factors for NPC, including folate intake $(<401.7 v s \geqslant 401.7 \mu \mathrm{g}$ per day), current drinking (yes $v s$ no), current smoking (yes $v s$ no), exposure to toxic substances (yes $v s$ no) and chronic rhinitis history (yes $v s$ no), we conducted a stratified analysis based on these factors. As these factors were not matched between NPC patients and control subjects, we used unconditional logistic regression adjusted for covariates rather than a conditional approach. Interactions were estimated via multiplicative interaction terms in the multivariate models.

\section{RESULTS}

Some key characteristics of the 600 case and control pairs (448 male pairs and 152 female pairs are shown in Table 1. The mean $( \pm$ s.d.) age for both NPC patients upon diagnosis and control subjects upon recruitment was $(47.4 \pm 9.0)$ years. NPC patients had a higher BMI than that of control subjects $(P=0.002)$. NPC patients were more likely to have a history of chronic rhinitis $(P<0.001)$ and to report lower intake of total energy $(P=0.029)$ and folate $(P<0.001)$. No significant difference was observed for current drinking, current smoking, exposure to toxic substances or physical activity.

The mean ( \pm s.d.) energy-adjusted intake of betaine was 264.5 $( \pm 180.5) \mathrm{mg}$ per day for NPC patients and $313.8( \pm 222.3) \mathrm{mg}$ per day for control subjects and that of total choline as $184.4( \pm 66.0)$ $\mathrm{mg}$ per day for NPC patients and 202.7 ( \pm 75.0$) \mathrm{mg}$ per day for control subjects (Table 1). NPC patients reported lower intake of total choline, phosphatidylcholine, free choline, glycerophosphocholine, and phosphocholine and betaine (all $P \leqslant 0.001$ ) (Table 1). Phosphatidylcholine made the greatest contribution to the total choline intake $(55.6 \%$ for NPC patients and $55.2 \%$ for control subjects), followed by free choline $(24.0 \%$ for NPC patients and $24.5 \%$ for control subjects) (Table 1). Overall, eggs (26.9\%) and Chinese flowering cabbage, mustard greens, collard greens and broccoli $(17.1 \%)$ contributed $>10 \%$ to the total choline intake; spinach, amaranth and water spinach $(79 \%)$ were the main sources of betaine (Table 2).

The five main choline-containing compounds were all significantly correlated (all $P<0.01$ ), and Pearson's correlation coefficients ranged from 0.108 to 0.767 for cases, and from 0.158 to 0.732 for controls (Table 3).

Associations between choline and betaine intake and NPC risk are shown in Table 4 . Both with and without adjustment for a number of lifestyle and dietary factors, a higher intake of total choline, betaine and total choline + betaine intake was associated with a significantly lower risk of NPC ( $P$-trend $<0.001$ for all). When the extreme quartiles of intake were compared, the adjusted OR $(95 \% \mathrm{CI})$ was $0.42(0.29,0.61)$ for total choline intake, 0.50 $(0.35,0.72)$ for betaine intake, and $0.44(0.30,0.64)$ for betaine + total choline intake.

\begin{tabular}{|c|c|c|c|}
\hline \multicolumn{4}{|c|}{$\begin{array}{l}\text { Table 1. Comparison of key characteristics between nasopharyngeal } \\
\text { carcinoma cases and controls }{ }^{a}\end{array}$} \\
\hline Characteristics & $\begin{array}{l}\text { Cases } \\
(n=600)\end{array}$ & $\begin{array}{l}\text { Controls } \\
(n=600)\end{array}$ & $\boldsymbol{P}$-value \\
\hline Age, years & $47.4 \pm 9.0$ & $47.4 \pm 9.0$ & 0.992 \\
\hline Body mass index, $\mathrm{kg} \mathrm{m}^{-2}$ & $23.2 \pm 3.1$ & $22.7 \pm 2.8$ & 0.002 \\
\hline Current drinking, $n(\%)^{\mathbf{b}}$ & $132(22.0)$ & $121(20.2)$ & 0.489 \\
\hline Current smoking, $n(\%)^{c}$ & $294(49.0)$ & 277 (46.2) & 0.343 \\
\hline Exposure to toxic substances, $n(\%)^{d}$ & $274(45.7)$ & $269(44.8)$ & 0.814 \\
\hline Chronic rhinitis history, $n(\%)$ & $164(27.3)$ & $108(18.0)$ & $<0.001$ \\
\hline Physical activity, MET•h per day ${ }^{\mathbf{e}}$ & $38.4 \pm 9.4$ & $39.5 \pm 11.8$ & 0.073 \\
\hline Total energy intake, kcal per day & $1873 \pm 600$ & $1953 \pm 642$ & 0.029 \\
\hline Folate intake, $\mu \mathrm{g}$ per day ${ }^{f}$ & $396.2 \pm 87.3$ & $419.6 \pm 96.3$ & $<0.001$ \\
\hline Total choline intake, mg per day ${ }^{f}$ & $184.4 \pm 66.0$ & $202.7 \pm 75.0$ & $<0.001$ \\
\hline $\begin{array}{l}\text { Phosphatidylcholine intake, mg per } \\
\text { day }^{f}\end{array}$ & $105.8 \pm 50.5$ & $116.2 \pm 59.0$ & 0.001 \\
\hline Free choline intake, mg per day ${ }^{f}$ & $42.2 \pm 13.7$ & $46.9 \pm 14.7$ & $<0.001$ \\
\hline $\begin{array}{l}\text { Glycerophosphocholine intake, mg } \\
\text { per day }{ }^{f}\end{array}$ & $16.9 \pm 5.5$ & $18.1 \pm 7.0$ & 0.001 \\
\hline Phosphocholine intake, mg per day ${ }^{f}$ & $13.1 \pm 7.2$ & $15.3 \pm 7.6$ & $<0.001$ \\
\hline Sphingomyelin intake, mg per day ${ }^{f}$ & $6.5 \pm 4.4$ & $6.4 \pm 4.6$ & 0.915 \\
\hline Betaine intake, mg per day ${ }^{f}$ & $264.5 \pm 180.5$ & $313.8 \pm 222.3$ & $<0.001$ \\
\hline 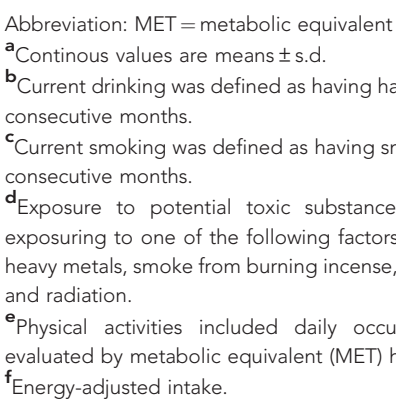 & $\begin{array}{l}\text { ase. } \\
\text { alcohol drink at le } \\
\text { or detrimental } \\
\text { over } 1 \text { year: heat, } \\
\text { nti-mosquito coils } \\
\text { ational, leisure-tir } \\
\text { urs per day. }\end{array}$ & $\begin{array}{l}\text { east once daily for } \\
\text { cigarette daily for } \\
\text { environment incl } \\
\text { organic solvents, } \\
\text {, new furniture or } \\
\text { me and househ }\end{array}$ & $\begin{array}{l}\text { at least six } \\
\text { at least six } \\
\text { uded ever } \\
\text { pesticides, } \\
\text { decoration } \\
\text { old-chores, }\end{array}$ \\
\hline
\end{tabular}

We also examined associations between the intake of the five main choline-containing compounds and NPC risk (Table 5). According to the multivariate analysis, NPC risk was inversely associated with the intake of choline from phosphatidylcholine $(P$-trend $=0.004)$, free choline $(P$-trend $<0.001)$, glycerophosphocholine $(P$-trend $=0.019)$ and phosphocholine $(P$-trend $<0.001)$, but not from sphingomyelin $(P$-trend $=0.207)$. Compared with the lowest quartile, the adjusted OR (95\% CI) of NPC risk for the highest quartile was $0.58(0.40,0.86)$ for phosphatidylcholine, $0.38(0.26,0.55)$ for free choline, 0.53 $(0.36,0.78)$ for glycerophosphocholine and $0.37(0.26,0.54)$ for phosphocholine.

Whether the potential risk factors modified the association between total choline and NPC risk is shown in Table 6. The association between total choline intake and NPC risk was stronger among patients without exposure to toxic substances than among patients with exposure ( $P$-trend: $<0.001$ vs 0.019 ; $P$-interaction: $0.013)$. In addition, we found the inverse association between total choline intake and NPC risk was only found among those without current alcohol intake $(P$-trend: $<0.001)$, but not among current drinkers ( $P$-trend: 0.093). However, the $P$-values for the interaction were insignificant ( $P$-interaction: 0.777$)$. We also did stratification for eggs intake $(<291.0 v s \geqslant 291.0 \mu \mathrm{g}$ per day), because it was the major source of total choline, but no interaction was observed $(P$-interaction $=0.829)($ data no shown $)$. 
Table 2. Top five contributors of food sources (percentage contribution to total intake) of betaine, total choline and choline-containing compounds among control subjects

\begin{tabular}{|c|c|}
\hline Food source & $\begin{array}{c}\text { Proportion } \\
\text { (\%) }\end{array}$ \\
\hline \multicolumn{2}{|l|}{ Total choline } \\
\hline $\begin{array}{l}\text { Eggs } \\
\text { Chinese flowering cabbage, mustard greens, collard greens } \\
\text { and broccoli } \\
\text { Poultry with skin } \\
\text { Rice } \\
\text { Nuts }\end{array}$ & $\begin{array}{l}26.9 \\
17.1 \\
8.2 \\
5.7 \\
4.5\end{array}$ \\
\hline \multicolumn{2}{|l|}{ Phosphatidylcholine (55.2\% of total choline) } \\
\hline $\begin{array}{l}\text { Eggs } \\
\text { Chinese flowering cabbage, mustard greens, collard greens } \\
\text { and broccoli } \\
\text { Poultry with skin } \\
\text { Spinach, amaranth, and water spinach } \\
\text { Nuts }\end{array}$ & $\begin{array}{l}44.3 \\
15.5 \\
9.5 \\
4.9 \\
4.8\end{array}$ \\
\hline \multicolumn{2}{|l|}{ Free choline ( $24.5 \%$ of total choline) } \\
\hline $\begin{array}{l}\text { Chinese flowering cabbage, mustard greens, collard greens } \\
\text { and broccoli } \\
\text { Pakchoi and lettuce } \\
\text { Rice } \\
\text { Chinese cabbage, white flower vegetables, and celery } \\
\text { Nuts }\end{array}$ & $\begin{array}{r}16.0 \\
12.9 \\
8.8 \\
7.4 \\
6.7\end{array}$ \\
\hline \multicolumn{2}{|l|}{ Glycerophosphocholine (9.7\% of total choline) } \\
\hline $\begin{array}{l}\text { Rice } \\
\text { Whole milk } \\
\text { Porridge } \\
\text { Chinese flowering cabbage, mustard greens, collard greens } \\
\text { and broccoli } \\
\text { Banana }\end{array}$ & $\begin{array}{r}29.5 \\
12.4 \\
10.1 \\
6.3 \\
6.1\end{array}$ \\
\hline \multicolumn{2}{|l|}{ Phosphocholine ( $7.7 \%$ of total choline) } \\
\hline $\begin{array}{l}\text { Chinese flowering cabbage, mustard greens, collard greens } \\
\text { and broccoli } \\
\text { Pakchoi and lettuce } \\
\text { Poultry with skin } \\
\text { Whole milk } \\
\text { Root vegetables }\end{array}$ & $\begin{array}{l}51.4 \\
9.5 \\
5.5 \\
3.5 \\
3.1\end{array}$ \\
\hline \multicolumn{2}{|l|}{ Sphingomyelin ( $3.0 \%$ of total choline) } \\
\hline $\begin{array}{l}\text { Poultry with skin } \\
\text { Eggs } \\
\text { Skinless poultry } \\
\text { Whole milk } \\
\text { Processed meat }\end{array}$ & $\begin{array}{r}43.8 \\
35.4 \\
10.5 \\
2.9 \\
2.5\end{array}$ \\
\hline \multicolumn{2}{|l|}{ Betaine } \\
\hline $\begin{array}{l}\text { Spinach, amaranth and water spinach } \\
\text { Noodles } \\
\text { Steamed buns } \\
\text { Whole-wheat bread } \\
\text { Root vegetables }\end{array}$ & $\begin{array}{r}79.0 \\
9.1 \\
4.1 \\
3.0 \\
1.5\end{array}$ \\
\hline
\end{tabular}

\section{DISCUSSION}

This hospital-based case-control study is, to the best of our knowledge, the first to examine and observe a significant inverse relationship between choline and betaine intakes and risk of NPC. Individual dietary sources of choline, that is, phosphatidylcholine, free choline, glycerophosphocholine, and phosphocholine, were also associated with NPC risk.

Recent epidemiological studies investigating the association between choline and betaine intake and various types of cancer, most of which were conducted in USA, have yielded conflicting findings. From a case-control study conducted in the same geographic area as our study, Zhang et al (2013) reported that intakes of choline and betaine were inversely related to the risk of breast cancer. Similar results were observed in a study by Xu et al (2009), but no associations were found in others (Cho et al, 2007a, 2010; Xu et al, 2008a,b). Higher intakes of choline and betaine were associated with a lower risk of lung cancer, but not with the risk of renal cell cancer (Cho et al, 2013), epithelial ovarian cancer (Kotsopoulos et al, 2010), colorectal cancer (Lee et al, 2010) or oesophageal cancer (Ibiebele et al, 2011). One study showed that increased choline intake had a detrimental effect on the incidence of and survival from lethal-type prostate cancer (Richman et al, 2012). Differences in types of cancers, study design, sample size, methods of measuring dietary nutrients and adjustment for covariates may account, at least in part, for the different findings across studies. In addition, comparing with other populations, Chinese usually consuming a lower level of dietary total choline (about $200 \mathrm{mg}$ per day among Chinese vs about $300 \mathrm{mg}$ per day among most of other populations), but a higher level of dietary betaine (about $310 \mathrm{mg}$ per day among Chinese vs 49.8 to $190 \mathrm{mg}$ per day among other populations), might also contribute to the inconsistencies (Cho et al, 2007a, 2010, 2013; Xu et al, 2008a,b; Kotsopoulos et al, 2010; Richman et al, 2012; Zhang et al, 2013). Our results were consistent with the findings of Zhang et al (2013), showing that higher intakes of choline and betaine can reduce the risk of NPC.

Regarding specific types of choline, we found choline from phosphatidylcholine, free choline, glycerophosphocholine and phosphocholine to be related to a lower risk of NPC. However, Zhang et al (2013) reported that all five of the main dietary sources of choline have a protective effect on breast cancer risk. The lack of an association between sphingomyelin and lower risk is probably due to the relatively low levels (mean levels for sphingomyelin $v s$ the other four sources (controls): $6.4 \mathrm{mg}$ per day vs $15.3-116.2 \mathrm{mg}$ per day). Thus, it might be more difficult to accurately measure sphingomyelin, which would lead to greater variation in the observed association.

In our study, choline was abundantly derived from eggs (26.9\%) and Chinese flowering cabbage, mustard greens, collard greens and broccoli $(17.1 \%)$, whereas the main sources of betaine were spinach, amaranth and water spinach (79\%). Chinese flowering cabbage, mustard greens, collard greens, broccoli and spinach, amaranth, and water spinach are all dark green leafy vegetables, and increasing the intake of dark green vegetables was associated with a lower risk of NPC in our previous study (Liu et al, 2012). This association is also supported by other studies (Zheng et al, 1994; Armstrong et al, 1998; Farrow et al, 1998; Yuan et al, 2000). However, eggs were inconsistently not related or positively related with the risk of larynx or pharyngeal cancer (Winn et al, 1984; Aune et al, 2009), and the beneficial effect of choline derived from eggs is probably offset by the significantly high cholesterol content, which has been shown to increase cancer risk (Kritchevsky and Kritchevsky, 1992).

Although the exact mechanisms by which high choline and betaine intakes protect against NPC risk are unclear, the association with carcinogenesis is biologically plausible. Overall, these two nutrients serve as methyl donors in one-carbon metabolism (Laird and Jaenisch, 1994). One-carbon metabolism affects the level of DNA methylation through a series of biochemical reactions involving in the transfer of methyl groups 
Table 3. Pearson's correlation coefficients for cases and controls among five main choline-containing compounds

\begin{tabular}{|c|c|c|c|c|c|c|c|c|}
\hline & \multicolumn{2}{|c|}{ Free choline } & \multicolumn{2}{|c|}{ Glycerophosphocholine } & \multicolumn{2}{|c|}{ Phosphocholine } & \multicolumn{2}{|c|}{ Sphingomyelin } \\
\hline & Cases & Controls & Cases & Controls & Cases & Controls & Cases & Controls \\
\hline Phosphatidylcholine & 0.407 & 0.356 & 0.140 & 0.158 & 0.412 & 0.346 & 0.660 & 0.711 \\
\hline Free choline & & & 0.468 & 0.485 & 0.767 & 0.732 & 0.108 & 0.172 \\
\hline Glycerophosphocholine & & & & & 0.334 & 0.354 & 0.115 & 0.208 \\
\hline Phosphocholine & & & & & & & 0.164 & 0.183 \\
\hline
\end{tabular}

Table 4. Risk of nasopharyngeal carcinoma for quartiles of dietary choline and betaine intake in Guangzhou, China

\begin{tabular}{|c|c|c|c|c|c|c|}
\hline & \multicolumn{2}{|c|}{ Cases $(n=600)$} & \multicolumn{2}{|c|}{ Controls $(n=600)$} & \multirow{2}{*}{$\begin{array}{l}\text { Without adjusted } \\
\text { Odds ratio }(95 \% \mathrm{Cl})\end{array}$} & \multirow{2}{*}{$\begin{array}{c}\text { Multivariate } \text { adjusted }^{\text {a }} \\
\text { Odds ratio }(95 \% \mathrm{Cl})\end{array}$} \\
\hline & Median (mg per day) ${ }^{b}$ & $n$ & Median (mg per day) ${ }^{b}$ & $n$ & & \\
\hline \multicolumn{7}{|c|}{ Quartile of total choline } \\
\hline Q1 & 125 & 204 & 121 & 150 & 1.00 & 1.00 \\
\hline $\mathrm{Q} 2$ & 170 & 180 & 173 & 150 & $0.86(0.63-1.17)$ & $0.80(0.57-1.11)$ \\
\hline Q3 & 218 & 116 & 216 & 150 & $0.53(0.38-0.75)$ & $0.45(0.31-0.66)$ \\
\hline Q4 & 285 & 100 & 286 & 150 & $0.47(0.33-0.66)$ & $0.42(0.29-0.61)$ \\
\hline$P$-trend & & & & & $<0.001$ & $<0.001$ \\
\hline \multicolumn{7}{|c|}{ Quartile of betaine } \\
\hline Q1 & 112 & 208 & 101 & 150 & 1.00 & 1.00 \\
\hline $\mathrm{Q} 2$ & 211 & 158 & 206 & 150 & $0.77(0.57-1.04)$ & $0.69(0.50-0.96)$ \\
\hline Q3 & 327 & 132 & 329 & 150 & $0.64(0.46-0.87)$ & $0.56(0.40-0.80)$ \\
\hline Q4 & 539 & 102 & 548 & 150 & $0.50(0.36-0.69)$ & $0.50(0.35-0.72)$ \\
\hline$P$-trend & & & & & $<0.001$ & $<0.001$ \\
\hline \multicolumn{7}{|c|}{ Quartile of total choline + betaine } \\
\hline Q1 & 285 & 222 & 278 & 150 & 1.00 & 1.00 \\
\hline $\mathrm{Q} 2$ & 411 & 155 & 407 & 150 & $0.69(0.51-0.93)$ & $0.63(0.45-0.89)$ \\
\hline Q3 & 530 & 127 & 558 & 150 & $0.55(0.40-0.76)$ & $0.48(0.34-0.69)$ \\
\hline Q4 & 761 & 96 & 779 & 150 & $0.42(0.30-0.59)$ & $0.44(0.30-0.64)$ \\
\hline$P$-trend & & & & & $<0.001$ & $<0.001$ \\
\hline \multicolumn{7}{|c|}{ 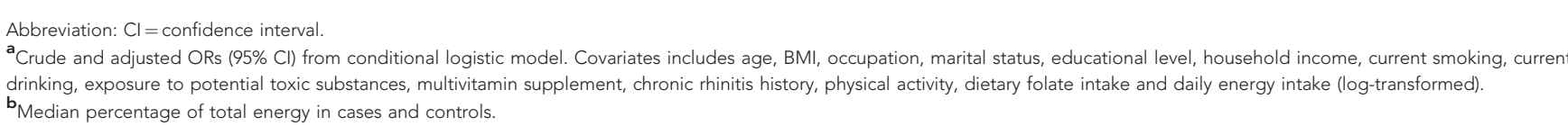 } \\
\hline
\end{tabular}

from one compound to another to generate the universal methyl donor S-adenosylmethionine (Laird and Jaenisch, 1994). Epigenetic variations in DNA, particularly CpG site methylation, have an important role in genome regulation (Lister et al, 2009). Deficiency of methyl donors in one-carbon metabolism leading to disruption of DNA methylation and impaired DNA repair are thought to be the main underlying mechanism for carcinogenesis (Davis and Uthus, 2004). Animal models have shown that a diet deficient in methyl (for example, folate, choline or methionine) causes decreased tissue S-adenosylmethionine, global DNA hypomethylation, hepatic steatosis, cirrhosis and ultimate hepatic tumorigenesis in rodents (Davis and Uthus, 2004). Furthermore, the variation in genes involved in choline and betaine metabolism, such as the G774C polymorphism in phosphatidylethanolamine $\mathrm{N}$-methyltransferase (PEMT, catalysing the methylation of phosphatidylethanolamine to form phosphatidylcholine) and the G432T polymorphism in choline dehydrogenase ( $\mathrm{CHDH}$, catalysing the oxidation of choline to betaine), have been associated with higher risk of breast cancer (Xu et al, 2008b), 742 GA polymorphism in betaine-homocysteine methyltransferase (BHMT, utilising betaine as the methyl donor to remethylate homocysteine to methionine) increased the risk of head and neck squamous cell carcinoma (da Silva et al, 2012).

We observed that exposure to toxic substances has a strong modifying effect on the association between choline intake and risk of NPC. The inverse association appeared to be particularly strong among those individuals without exposure to toxic substances, especially for the third quartile (OR for Q3 vs Q1: 0.35 vs 0.87, $P$-interaction $=0.013$ ). Toxic substances (for example, fumes, smoke and chemicals) are traditional risk factors for NPC, and exposure to such substances can significantly increase the risk of NPC (Henderson et al, 1976). Toxicity studies on vertebrates have shown that chemicals (for example, the widely used alkanolamines) can inhibit cellular choline uptake and cause choline deficiency (Hansen et al, 2010). Thus, we can hypothesise that toxic substances mitigate the protective effect of choline intake on 
Table 5. Risk of nasopharyngeal carcinoma for quartiles of five main choline-containing compound intakes in Guangzhou, China

\begin{tabular}{|c|c|c|c|c|c|c|}
\hline & \multicolumn{2}{|l|}{ Cases $(n=600)$} & \multicolumn{2}{|c|}{ Controls $(n=600)$} & \multirow{2}{*}{$\begin{array}{l}\text { Without adjusted } \\
\text { Odds ratio }(95 \% \mathrm{Cl})\end{array}$} & \multirow{2}{*}{\begin{tabular}{|l|} 
Multivariate adjusted \\
Odds ratio $(95 \% \mathrm{Cl})$
\end{tabular}} \\
\hline & Median (mg per day) & $\mathbf{n}$ & Median (mg per day) ${ }^{b}$ & $n$ & & \\
\hline \multicolumn{7}{|c|}{ Quartile of phosphatidylcholine } \\
\hline Q1 & 61.5 & 191 & 58.6 & 150 & 1.00 & 1.00 \\
\hline Q2 & 91.8 & 163 & 93.0 & 150 & $0.85(0.62-1.16)$ & $0.83(0.59-1.16)$ \\
\hline Q3 & 120.0 & 132 & 122.6 & 150 & $0.67(0.48-0.93)$ & $0.66(0.45-0.95)$ \\
\hline Q4 & 175.6 & 114 & 179.8 & 150 & $0.56(0.40-0.79)$ & $0.58(0.40-0.86)$ \\
\hline$P$-trend & & & & & $<0.001$ & 0.004 \\
\hline \multicolumn{7}{|c|}{ Quartile of free choline } \\
\hline Q1 & 31.1 & 233 & 31.1 & 150 & 1.00 & 1.00 \\
\hline Q2 & 40.6 & 152 & 40.6 & 150 & $0.64(0.47-0.88)$ & $0.61(0.43-0.84)$ \\
\hline Q3 & 49.3 & 118 & 49.7 & 150 & $0.49(0.35-0.68)$ & $0.41(0.29-0.59)$ \\
\hline Q4 & 61.3 & 97 & 63.4 & 150 & $0.41(0.29-0.58)$ & $0.38(0.26-0.55)$ \\
\hline$P$-trend & & & & & $<0.001$ & $<0.001$ \\
\hline \multicolumn{7}{|c|}{ Quartile of glycerophosphocholine } \\
\hline Q1 & 11.8 & 165 & 11.8 & 150 & 1.00 & 1.00 \\
\hline Q2 & 14.8 & 154 & 14.9 & 150 & $0.94(0.68-1.28)$ & $0.96(0.68-1.35)$ \\
\hline Q3 & 18.1 & 181 & 18.2 & 150 & $1.09(0.80-1.49)$ & $1.16(0.82-1.65)$ \\
\hline Q4 & 25.3 & 100 & 25.4 & 150 & $0.60(0.43-0.85)$ & $0.53(0.36-0.78)$ \\
\hline$P$-trend & & & & & 0.026 & 0.019 \\
\hline \multicolumn{7}{|c|}{ Quartile of phosphocholine } \\
\hline Q1 & 7.5 & 234 & 7.5 & 150 & 1.00 & 1.00 \\
\hline $\mathrm{Q} 2$ & 11.6 & 164 & 12.1 & 150 & $0.69(0.50-0.95)$ & $0.60(0.42-0.86)$ \\
\hline Q3 & 16.1 & 100 & 16.5 & 150 & $0.40(0.28-0.57)$ & $0.33(0.22-0.48)$ \\
\hline Q4 & 23.5 & 102 & 23.7 & 150 & $0.43(0.31-0.60)$ & $0.37(0.26-0.54)$ \\
\hline$P$-trend & & & & & $<0.001$ & $<0.001$ \\
\hline \multicolumn{7}{|c|}{ Quartile of sphingomyelin } \\
\hline Q1 & 2.27 & 141 & 1.86 & 150 & 1.00 & 1.00 \\
\hline Q2 & 4.54 & 167 & 4.36 & 150 & $1.19(0.86-1.65)$ & $1.08(0.76-1.55)$ \\
\hline Q3 & 7.01 & 165 & 6.86 & 150 & $1.17(0.85-1.61)$ & $1.02(0.72-1.45)$ \\
\hline Q4 & 12.10 & 127 & 11.35 & 150 & $0.88(0.63-1.25)$ & $0.79(0.54-1.15)$ \\
\hline$P$-trend & & & & & 0.545 & 0.207 \\
\hline $\begin{array}{l}\text { Abbreviati } \\
{ }^{\mathrm{a}} \text { Adjusted } \\
\mathrm{b}_{\text {Median }}\end{array}$ & $\begin{array}{l}\text { fidence interval. } \\
\text { Cl) from conditional logistic mo } \\
\text { of total energy in cases and co }\end{array}$ & ovaria & sted see Table 4. & & & \\
\hline
\end{tabular}

NPC by affecting choline metabolism. However, the nonlinear trend for those never exposed to toxic substances needs further study for elucidation of the underlying mechanisms of this finding.

The strengths of the study are the relatively large number of subjects, the good matching by age, sex and residence between the NPC patients and the control subjects, the use of a validated and reproducible FFQ (Zhang and Ho, 2009; Zhang et al, 2013), assessment of portion size by means of visual aids, the trained interviewers and the equal number of patient and control interviews conducted by the individual investigators.

The results of this study should be interpreted in light of several limitations. First, reverse causality could not be fully excluded in a case-control study, because the diet data were collected after the diagnoses of NPC. We minimised this possibility by including only incident cases and by meticulously excluding individuals with essential changes in their diet habits in recent 5 years. Of course, cohort study design is an ideal way to overcome this defect. Up to date, few prospective cohort studies have focused on NPC and all of them had a small number of NPC cases (all $<200$ cases) due to a low incidence (Chien et al, 2001; Li et al, 2006; Friborg et al, 2007; Hsu et al, 2011). Second, inaccurate recall of habitual diet is unavoidable in retrospective studies, but differential report between cases and controls was unlikely to be present in this study as there was little public awareness about dietary choline/betaine and its potential to cancer risk. Third, NPC patients and control subjects were recruited from two different hospital centres, which might influence the representations. However, both centres were the top ranking specialised hospitals in the South China with comparable reputation and coverage area. The major demographic characteristics (for example, age, sex) of our case patients were comparable to those in a population-based NPC epidemiological survey (Jia et al, 2006). Fourth, the use of hospital patients as control subjects is a potential limitation because their dietary habits may differ from those of the general healthy population in the same catchment area. However, we included only control subjects with conditions (for example, ocular fundus disease, ocular trauma, glaucoma and ophthalmic plastic surgery) not related to long-term dietary modifications. Further, the use of hospital control subjects 
Table 6. Risk of nasopharyngeal carcinoma for quartiles of total choline intake by risk factors and eggs intake in Guangzhou, China ${ }^{a}$

\begin{tabular}{|c|c|c|}
\hline Quartile of total choline & $\begin{array}{l}\text { Odds ratio } \\
(95 \% \mathrm{Cl})\end{array}$ & $\begin{array}{c}\text { Odds ratio } \\
(95 \% \mathrm{Cl})\end{array}$ \\
\hline Folate intake & $<401.7 \mu$ g per day & $\geqslant 401.7 \mu \mathrm{g}$ per day \\
\hline Q1 & 1.00 & 1.00 \\
\hline Q2 & $0.73(0.48-1.10)$ & $1.07(0.63-1.81)$ \\
\hline Q3 & $0.46(0.28-0.76)$ & $0.62(0.37-1.04)$ \\
\hline Q4 & $0.41(0.23-0.73)$ & $0.57(0.34-0.96)$ \\
\hline$P$-trend & $<0.001$ & 0.005 \\
\hline$P$-interaction & \multicolumn{2}{|c|}{0.420} \\
\hline Current smoking & Yes & No \\
\hline Q1 & 1.00 & 1.00 \\
\hline Q2 & $0.99(0.56-1.76)$ & $0.75(0.41-1.37)$ \\
\hline Q3 & $0.42(0.22-0.81)$ & $0.40(0.21-0.79)$ \\
\hline Q4 & $0.35(0.18-0.68)$ & $0.39(0.20-0.78)$ \\
\hline$P$-trend & 0.006 & 0.028 \\
\hline$P$-interaction & \multicolumn{2}{|c|}{0.795} \\
\hline Current drinking & Yes & No \\
\hline Q1 & 1.00 & 1.00 \\
\hline Q2 & $1.49(0.70-3.18)$ & $0.71(0.50-1.01)$ \\
\hline Q3 & $0.66(0.30-1.45)$ & $0.48(0.33-0.72)$ \\
\hline Q4 & $0.60(0.27-1.34)$ & $0.44(0.29-0.67)$ \\
\hline$P$-trend & 0.093 & $<0.001$ \\
\hline$P$-interaction & \multicolumn{2}{|c|}{0.777} \\
\hline Exposure to toxic substances & Yes & No \\
\hline Q1 & 1.00 & 1.00 \\
\hline Q2 & $0.98(0.62-1.54)$ & $0.72(0.46-1.12)$ \\
\hline Q3 & $0.87(0.54-1.42)$ & $0.35(0.22-0.57)$ \\
\hline $\mathrm{Q} 4$ & $0.50(0.30-0.86)$ & $0.46(0.28-0.76)$ \\
\hline$P$-trend & 0.019 & $<0.001$ \\
\hline$P$-interaction & \multicolumn{2}{|c|}{0.013} \\
\hline Chronic rhinitis history & Yes & No \\
\hline Q1 & 1.00 & 1.00 \\
\hline Q2 & $0.60(0.30-1.21)$ & $0.94(0.66-1.35)$ \\
\hline Q3 & $0.54(0.25-1.19)$ & $0.51(0.35-0.76)$ \\
\hline Q4 & $0.29(0.13-0.65)$ & $0.55(0.36-0.84)$ \\
\hline$P$-trend & 0.003 & $<0.001$ \\
\hline$P$-interaction & \multicolumn{2}{|c|}{0.896} \\
\hline $\begin{array}{l}\text { Abbreviation: } \mathrm{Cl}=\text { confidence interv } \\
\text { a Adjusted ORs }(95 \% \mathrm{Cl}) \text { from un } \\
\text { Table } 4 \text {. }\end{array}$ & ditional logistic model. & Covariates adjusted: see \\
\hline
\end{tabular}

tends to reduce differential report on diet (B DA et al, 1996). Fifth, the reliability of estimated choline and betaine intake should be considered. Although the databases from the USA allowed us to quantify a broad range of choline and betaine intakes, the nutrient content of foods may vary by geographic origin, growing season, different cultivars, agricultural methods and processing (Cassidy et al, 2011). This information was not available to us, and some measurement error is inevitable, but the results seem to be not significantly affected because the choline and betaine contents of the main source foods (for example, vegetables) are similar, whether these foods are cooked or raw (Zeisel et al, 2003a,b). In addition, our analysis was based on a single measurement of dietary intake; thus, any misclassification could skew any true association (Schatzkin et al, 2003). Sixth, although we adjusted a wide range of dietary and lifestyle factors known to potentially affect cancer risk and the multivariate analysis yielded results similar to those of crude analysis, we could not rule out the possibility of bias from residual confounding. Seventh, high choline and betaine intake may be representative of a healthy lifestyle in general; however, a significant association was observed with betaine but not with all types of choline, thus the possibility of residual confounding by a healthy lifestyle may have been minimised. Eighth, high intakes of dark green leafy vegetables are a major source of these exposures. We could not rule out the influence of those co-existing bioactive compounds that might prevent nasopharyngeal oncogenesis (Hsu et al, 2012; Polesel et al, 2012). Moreover, we did not research on the genetic susceptibility, such as polymorphisms in PEMT, $\mathrm{CHDH}$ and BHMT involving in choline or betaine metabolism.

In conclusion, our study supports a protective role of choline and betaine intakes against the development of NPC. Given the findings obtained in similar populations for breast cancer (Zhang et al, 2013), these data suggest the importance of choline and betaine intake in the process of carcinogenesis. Considering the pitfalls of hospital-based case-control studies, our findings need confirmation by large well-designed studies, especially large-scale cohort studies.

\section{ACKNOWLEDGEMENTS}

We are grateful for the help from the doctors and nurses in two university affiliated hospitals (the Cancer Center and Ophthalmic Center) of Sun Yat-sen University for facilitating the recruitment and interviews. This study was supported by the 5010 Program for Clinical Researches of Sun Yat-sen University, Guangzhou, China (2007032).

\section{CONFLICT OF INTEREST}

The authors declare no conflict of interest.

\section{REFERENCES}

Armstrong RW, Imrey PB, Lye MS, Armstrong MJ, Yu MC, Sani S (1998) Nasopharyngeal carcinoma in Malaysian Chinese: salted fish and other dietary exposures. Int J Cancer 77: 228-235.

Aune D, De Stefani E, Ronco AL, Boffetta P, Deneo-Pellegrini H, Acosta G, Mendilaharsu M (2009) Egg consumption and the risk of cancer: a multisite case-control study in Uruguay. Asian Pac J Cancer Prev 10: 869-876.

B DA, La Vecchia C, Katsouyanni K, Negri E, Trichopoulos D (1996) Reliability of information on cigarette smoking and beverage consumption provided by hospital controls. Epidemiology 7: 312-315.

Bray F, Haugen M, Moger TA, Tretli S, Aalen OO, Grotmol T (2008) Age-incidence curves of nasopharyngeal carcinoma worldwide: bimodality in low-risk populations and aetiologic implications. Cancer Epidemiol Biomarkers Prev 17: 2356-2365.

Cassidy A, O’Reilly EJ, Kay C, Sampson L, Franz M, Forman JP, Curhan G, Rimm EB (2011) Habitual intake of flavonoid subclasses and incident hypertension in adults. Am J Clin Nutr 93: 338-347.

Chien YC, Chen JY, Liu MY, Yang HI, Hsu MM, Chen CJ, Yang CS (2001) Serologic markers of Epstein-Barr virus infection and nasopharyngeal carcinoma in Taiwanese men. N Engl J Med 345: 1877-1882.

Cho E, Giovannucci EL, Joh HK (2013) Nutrients related to one-carbon metabolism and risk of renal cell cancer. Cancer Causes Control 24: 373-382.

Cho E, Holmes M, Hankinson SE, Willett WC (2007a) Nutrients involved in one-carbon metabolism and risk of breast cancer among premenopausal women. Cancer Epidemiol Biomarkers Prev 16: 2787-2790.

Cho E, Holmes MD, Hankinson SE, Willett WC (2010) Choline and betaine intake and risk of breast cancer among post-menopausal women. Br J Cancer 102: 489-494. 
Cho E, Willett WC, Colditz GA, Fuchs CS, Wu K, Chan AT, Zeisel SH, Giovannucci EL (2007b) Dietary choline and betaine and the risk of distal colorectal adenoma in women. J Natl Cancer Inst 99: 1224-1231.

da Silva LM, Galbiatti AL, Ruiz MT, Raposo LS, Maniglia JV, Pavarino EC, Goloni-Bertollo EM (2012) MTHFD1 G1958A, BHMT G742A, TC2 C776G and TC2 A67G polymorphisms and head and neck squamous cell carcinoma risk. Mol Biol Rep3 9: 887-893.

Davis CD, Uthus EO (2004) DNA methylation, cancer susceptibility, and nutrient interactions. Exp Biol Med 229(10): 988-995.

Farrow DC, Vaughan TL, Berwick M, Lynch CF, Swanson GM, Lyon JL (1998) Diet and nasopharyngeal cancer in a low-risk population. Int J Cancer 78: 675-679.

Ferlay J, Shin HR, Bray F, Forman D, Mathers C, Parkin DM (2008) GLOBOCAN 2008 v2.0, Cancer Incidence and Mortality Worldwide. IARC CancerBase No. 10 [Internet] In: International Agency for Research on Cancer: Lyon, France, 2010. Available from http://globocan.iarc.fr/ accessed on 15/07/2013.

Friborg JT, Yuan JM, Wang R, Koh WP, Lee HP, Yu MC (2007) A prospective study of tobacco and alcohol use as risk factors for pharyngeal carcinomas in Singapore Chinese. Cancer 109: 1183-1191.

Hansen BH, Altin D, Booth A, Vang SH, Frenzel M, Sorheim KR, Brakstad OG, Storseth TR (2010) Molecular effects of diethanolamine exposure on Calanus finmarchicus (Crustacea: Copepoda). Aquat Toxicol 99: $212-222$.

Henderson BE, Louie E, SooHoo Jing J, Buell P, Gardner MB (1976) Risk factors associated with nasopharyngeal carcinoma. N Engl J Med2 95: 1101-1106.

Hsu WL, Pan WH, Chien YC, Yu KJ, Cheng YJ, Chen JY, Liu MY, Hsu MM, Lou PJ, Chen IH, Yang CS, Hildesheim A, Chen CJ (2012) Lowered risk of nasopharyngeal carcinoma and intake of plant vitamin, fresh fish, green tea and coffee: a case-control study in Taiwan. PLoS One 7: e41779.

Hsu WL, Yu KJ, Chien YC, Chiang CJ, Cheng YJ, Chen JY, Liu MY, Chou SP, You SL, Hsu MM, Lou PJ, Wang CP, Hong JH, Leu YS, Tsai MH, Su MC, Tsai ST, Chao WY, Ger LP, Chen PR, Yang CS, Hildesheim A, Diehl SR, Chen CJ (2011) Familial tendency and risk of nasopharyngeal carcinoma in taiwan: effects of covariates on risk. Am J Epidemiol 173(3): 292-299.

Ibiebele TI, Hughes MC, Pandeya N, Zhao Z, Montgomery G, Hayward N, Green AC, Whiteman DC, Webb PM (2011) High intake of folate from food sources is associated with reduced risk of esophageal cancer in an Australian population. J Nutr 141: 274-283.

Jia WH, Huang QH, Liao J, Ye W, Shugart YY, Liu Q, Chen LZ, Li YH, Lin X, Wen FL, Adami HO, Zeng Y, Zeng YX (2006) Trends in incidence and mortality of nasopharyngeal carcinoma over a 20-25 year period (1978/ 1983-2002) in Sihui and Cangwu counties in southern China. BMC Cancer 6: 178 .

Kotsopoulos J, Hankinson SE, Tworoger SS (2010) Dietary betaine and choline intake are not associated with risk of epithelial ovarian cancer. Eur J Clin Nutr 64: 111-114.

Kritchevsky SB, Kritchevsky D (1992) Serum cholesterol and cancer risk: an epidemiologic perspective. Annu Rev Nutr 12: 391-416.

Laird PW, Jaenisch R (1994) DNA methylation and cancer. Hum Mol Genet 3(suppl 1): 1487-1495.

Lee AW, Foo W, Mang O, Sze WM, Chappell R, Lau WH, Ko WM (2003) Changing epidemiology of nasopharyngeal carcinoma in Hong Kong over a 20-year period (1980-99): an encouraging reduction in both incidence and mortality. Int $J$ Cancer 103: 680-685.

Lee JE, Giovannucci E, Fuchs CS, Willett WC, Zeisel SH, Cho E (2010) Choline and betaine intake and the risk of colorectal cancer in men. Cancer Epidemiol Biomarkers Prev 19: 884-887.

Li W, Ray RM, Gao DL, Fitzgibbons ED, Seixas NS, Camp JE, Wernli KJ, Astrakianakis G, Feng Z, Thomas DB, Checkoway H (2006) Occupational risk factors for nasopharyngeal cancer among female textile workers in Shanghai, China. Occup Environ Med 63: 39-44.

Lister R, Pelizzola M, Dowen RH, Hawkins RD, Hon G, Tonti-Filippini J, Nery JR, Lee L, Ye Z, Ngo QM, Edsall L, Antosiewicz-Bourget J, Stewart R, Ruotti V, Millar AH, Thomson JA, Ren B, Ecker JR (2009) Human DNA methylomes at base resolution show widespread epigenomic differences. Nature 462: 315-322.

Liu YT, Dai JJ, Xu CH, Lu YK, Fan YY, Zhang XL, Zhang CX, Chen YM (2012) Greater intake of fruit and vegetables is associated with lower risk of nasopharyngeal carcinoma in Chinese adults: a case-control study. Cancer Causes Control 23: 589-599.
Polesel J, Negri E, Serraino D, Parpinel M, Barzan L, Libra M, Bosetti C, Garavello W, Montella M, La Vecchia C, Franceschi S, Talamini R (2012) Dietary intakes of carotenoids and other nutrients in the risk of nasopharyngeal carcinoma: a case-control study in Italy. $\mathrm{Br} J$ Cancer 107(9): 1580-1583.

Richman EL, Kenfield SA, Stampfer MJ, Giovannucci EL, Zeisel SH, Willett WC, Chan JM (2012) Choline intake and risk of lethal prostate cancer: incidence and survival. Am J Clin Nutr 96: 855-863.

Schatzkin A, Kipnis V, Carroll RJ, Midthune D, Subar AF, Bingham S, Schoeller DA, Troiano RP, Freedman LS (2003) A comparison of a food frequency questionnaire with a 24-hour recall for use in an epidemiological cohort study: results from the biomarker-based Observing Protein and Energy Nutrition (OPEN) study. Int J Epidemiol 32: 1054-1062.

Shin W, Yan J, Abratte CM, Vermeylen F, Caudill MA (2010) Choline intake exceeding current dietary recommendations preserves markers of cellular methylation in a genetic subgroup of folate-compromised men. J Nutr 140: 975-980.

Willett WC, Sampson L, Browne ML, Stampfer MJ, Rosner B, Hennekens CH, Speizer FE (1988) The use of a self-administered questionnaire to assess diet four years in the past. Am J Epidemiol 127: 188-199.

Winn DM, Ziegler RG, Pickle LW, Gridley G, Blot WJ, Hoover RN (1984) Diet in the etiology of oral and pharyngeal cancer among women from the southern United States. Cancer Res 44: 1216-1222.

Xu X, Gammon MD, Wetmur JG, Bradshaw PT, Teitelbaum SL, Neugut AI, Santella RM, Chen J (2008a) B-vitamin intake, one-carbon metabolism, and survival in a population-based study of women with breast cancer. Cancer Epidemiol Biomarkers Prev 17: 2109-2116.

Xu X, Gammon MD, Zeisel SH, Bradshaw PT, Wetmur JG, Teitelbaum SL, Neugut AI, Santella RM, Chen J (2009) High intakes of choline and betaine reduce breast cancer mortality in a population-based study. FASEB J 23: 4022-4028.

Xu X, Gammon MD, Zeisel SH, Lee YL, Wetmur JG, Teitelbaum SL, Bradshaw PT, Neugut AI, Santella RM, Chen J (2008b) Choline metabolism and risk of breast cancer in a population-based study. FASEB $J$ 22: 2045-2052.

Yang YX, Wang GY, Pan XC (2004) China food composition table. Beijing University Medical Press: Peking.

Ying J, Rahbar MH, Hallman DM, Hernandez LM, Spitz MR, Forman MR, Gorlova OY (2013) Associations between dietary intake of choline and betaine and lung cancer risk. PLoS One 8: e54561.

Yuan JM, Wang XL, Xiang YB, Gao YT, Ross RK, Yu MC (2000) Preserved foods in relation to risk of nasopharyngeal carcinoma in Shanghai, China. Int J Cancer 85: 358-363.

Zeisel SH, Da Costa KA, Franklin PD, Alexander EA, Lamont JT, Sheard NF, Beiser A (1991) Choline, an essential nutrient for humans. FASEB J 5: 2093-2098.

Zeisel SH, Mar MH, Howe JC, Holden JM (2003a) Concentrations of choline-containing compounds and betaine in common foods. J Nutr 133: 1302-1307.

Zeisel SH, Mar MH, Howe JC, Holden JM (2003b) Erratum: concentrations of choline-containing compounds and betaine in common foods. J Nutr 133: 2918-2919.

Zhang CX, Ho SC (2009) Validity and reproducibility of a food frequency Questionnaire among Chinese women in Guangdong province. Asia Pac J Clin Nutr 18: 240-250.

Zhang CX, Pan MX, Li B, Wang L, Mo XF, Chen YM, Lin FY, Ho SC (2013) Choline and betaine intake is inversely associated with breast cancer risk: a two-stage case-control study in China. Cancer Sci 104: 250-258.

Zheng YM, Tuppin P, Hubert A, Jeannel D, Pan YJ, Zeng Y, de The G (1994) Environmental and dietary risk factors for nasopharyngeal carcinoma: a case-control study in Zangwu County, Guangxi, China. Br J Cancer 69(3): 508-514.

This work is published under the standard license to publish agreement. After 12 months the work will become freely available and the license terms will switch to a Creative Commons AttributionNonCommercial-Share Alike 3.0 Unported License. 


\section{APPENDIX}

Table A1. Comparison of results of matched and unmatched analyses ${ }^{a}$

\begin{tabular}{|l|c|c|c|c|}
\cline { 2 - 4 } & \multicolumn{2}{|c|}{ Matched } & \multicolumn{2}{c|}{ Unmatched } \\
\cline { 2 - 5 } & Odds ratio $(95 \% \mathrm{Cl})$ & $\boldsymbol{P}$-trend & Odds ratio $(95 \% \mathrm{Cl})$ & $\boldsymbol{P}$-trend \\
\hline Total choline & $0.42(0.29,0.61)$ & $<0.001$ & $0.49(0.34,0.70)$ & 0.003 \\
\hline Phosphatidylcholine & $0.58(0.40,0.86)$ & 0.004 & $0.62(0.43,0.88)$ & $<0.001$ \\
\hline Free choline & $0.38(0.26,0.55)$ & $<0.001$ & $0.61(0.43,0.85)$ & 0.026 \\
\hline Glycerophosphocholine & $0.53(0.36,0.78)$ & 0.019 & $0.45(0.32,0.63)$ & $<0.001$ \\
\hline Phosphocholine & $0.37(0.26,0.54)$ & $<0.001$ & $0.81(0.57,1.14)$ & 0.231 \\
\hline Sphingomyelin & $0.79(0.54,1.15)$ & 0.207 & $0.49(0.35,0.69)$ & $<0.001$ \\
\hline Betaine & $0.50(0.35,0.72)$ & $<0.001$ & $0.42(0.30,0.60)$ & $<0.001$ \\
\hline Betaine + total choline & $0.44(0.30,0.64)$ & $<0.001$ & & $<$ \\
\hline
\end{tabular}

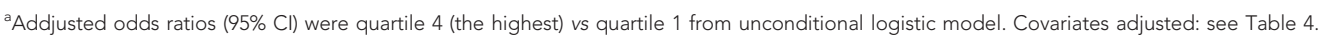

